\title{
Range of horizontal transport and residence time of nitrate in a mature karst vadose zone
}

\author{
Jiri Kamas ${ }^{1}$, Jiri Bruthans ${ }^{1 *}$, Helena Vysoka ${ }^{1}$, Miroslav Kovařik ${ }^{2}$ \\ ${ }^{1}$ Faculty of Science, Charles University in Prague, Albertov 6, 12843 Prague 2, Czech Republic \\ ${ }^{2}$ Nature Conservation Agency of the Czech Republic, Svitavská 29, 67801 Blansko, Czech Republic
}

\begin{abstract}
Nitrate concentrations in drips in Amaterska, Spolecnak, and Holstejnska caves situated below a 25 to $120 \mathrm{~m}$ thick vadose zone in the Moravian Karst, Central Europe were studied during several periods from 1992. Each cave runs below a land-use boundary between fertilized lands and forest, which enabled study of the range of horizontal components of nitrate transport in the vadose zone. Parts of the fertilized land were turned into grassland in 1998 and 2003, and the cave drips were sampled both prior and after the changes in land use. The mean residence time of nitrate is $<10$ years in the $25-30 \mathrm{~m}$ thick vadose zone, but $>16$ years in the $105-120 \mathrm{~m}$ thick vadose zone. The maximum range of horizontal nitrate transport $\left(\mathrm{H}_{\max }\right)$ is $18 \mathrm{~m}$ in the $105-120 \mathrm{~m}$ thick vadose zone. $\mathrm{H}_{\max }$ was normalized by the vadose zone's thickness $(T)$. In the Moravian Karst the $H_{\max } / T$ ratio is $<0.2$. A low $H_{\max } / T$ between 0.1 and 0.6 was observed in the Czech and Slovenian karst areas, unaffected by glaciations, and with an epikarst having evolved at least from the Pliocene. On the contrary, a high $\mathrm{H}_{\max } / \mathrm{T}$ (1.6-24) was reported from those areas affected by glaciations or mining activities, where the epikarst zone might be partly removed or sealed, and where shallow soils do not store much water after heavy rains. More data on the horizontal transport of tracers within the vadose zone are needed in order to test the potential relationship between epikarst development and $\mathrm{H}_{\max } / \mathrm{T}$.
\end{abstract}

Keywords: $\quad$ nitrate; epikarst; vadose zone; transport; residence time

Received 17 May 2014; Revised 22 October 2014; Accepted 28 October 2014

Citation: Kamas J., Bruthans J., Vysoka H. and Kovařík M., 2014. Range of horizontal transport and residence time of nitrate in a mature karst vadose zone. International Journal of Speleology, 44 (1), 49-59. Tampa, FL (USA) ISSN 0392-6672

http://dx.doi.org/10.5038/1827-806X.44.1.5

\section{INTRODUCTION}

Double to triple porosity, typical for karst, encompasses: conduits, which are dissolution tubular openings; fracture porosity; and matrix storage (Ford $\&$ Williams, 2007). Conduits occupy only a tiny fraction of an aquifer (0.003-0.02\%) in dense well-lithified limestone (Worthington et al., 2000). As the conduits drain most of the water there, the mean residence time is extremely short, typically just hours to days. Fracture and matrix porosity occupy $1-2 \%$ in dense well-lithified limestone; in the case of diffuse recharge, the residence times are often measured in years to decades (Einsiedl, 2005). The karst vadose zone (consisting of the soil, epikarst, and a transmission zone) plays a crucial role for ground water recharge and contaminant attenuation (Pronk et al., 2009; Ravbar \& Goldscheider, 2009). The residence time of water and dissolved matter in the karst vadose zone is usually studied by stable isotopes of oxygen or hydrogen, and less commonly by tritium (Perrin et al., 2003a; Kluge et al., 2010). In the temperate climatic zone, the residence times within a karst vadose zone of several tens of meters thickness is estimated at from several months to several years (Atkinson et al., 1985; Perrin et al., 2003a; Trček, 2007; Schwartz et al., 2009; Kluge et al., 2010).

As the permeability in a karst vadose zone decreases with depth, a considerable horizontal component of the flow often occurs in the epikarst (Smart \& Friederich, 1986; Motyka et al., 2001). Water flow converges towards major deep penetrating fissures (Williams, 1983; Williams, 2008; Klimchouk, 2000). Therefore, water and contaminant transport in the vadose zone always have both a vertical and horizontal component. In some areas, the horizontal component dominates (Smart \& Friederich, 1986; Motyka et al., 2001); in others, the vertical component dominates (Kogovšek \& Šebela, 2004). It remains unclear which factors are controlling the proportions of these horizontal and vertical components. As the permeability of vertical fractures increases over time in the vadose 
zone, a decrease of the horizontal component is to be anticipated, theoretically, if sufficient time is available for epikarst evolution (Williams, 1983).

Natural sources of nitrate include wildlife waste and the degradation of organic matter in the soil. The present-day background is elevated against the former natural background due to atmospheric inputs, which include both combustion products and the evaporation of ammonia from fertilizers and livestock wastes. A present-day background of $11 \mathrm{mg} / 1$ (the concentration as $\mathrm{NO}_{3}$ is used in this paper) was identified in karst springs by Panno et al. (2006). An extensive review, including data from tens of thousands wells and springs, has shown that the present-day background nitrate concentration in the USA is about 9 mg/1 (USGS, 2002; Panno et al., 2006). Septic effluents, livestock wastes, and synthetic fertilizers are sources of high nitrate concentrations, exceeding present-day background levels (Kastrinos \& White 1986; Panno et al., 2006). Karst aquifers often have a higher nitrate content (Boyer \& Pasquarell, 1995), and nitrate is the most common contaminant (Iqbal \& Krothe, 1995; Peterson et al., 2002). A strong linear relationship between the nitrate concentration in karst springs and the percentage of agricultural land was found by Kastrinos \& White (1986) and Boyer \& Pasquarell (1995). Movement of nitrate in the soil by matrix flow, with a rate of $65 \mathrm{~cm} /$ year, was described by Peterson et al. (2002). Iqbal \& Krothe (1995) described the major movement of nitrate in quick pulses through the vadose zone immediately after a major storm event. The relatively long residence time (tens of years) of nitrate in a karst vadose zone was described by Katz et al. (2004).

The Moravian Karst (Czech Rep.; Fig. 1) represents an ideal area in which to study nitrate transport in the vadose zone. Extensive horizontal cave passages, mostly situated from 25 to $120 \mathrm{~m}$ below the ground surface, enable relatively easy access and sampling of water from the vadose zone. In some areas, the cave passages traverse below the land-use boundary between forest/grassland and fertilized land. Fertilizers have been intensively applied since 1960 (Balák et al., 1999). Maximum nitrate concentrations in cave drips, which were located below fertilized lands in the area were $115 \mathrm{mg} / 1$ in 1981 and $136 \mathrm{mg} / 1$ in 1995; while nitrate concentrations under forests was only 5-11 mg/1, on average (Balák et al., 1999; Table 1).

The intensive production of maize in the immediate surroundings of dolines caused heavy erosion of the soil cover and the transport of mud into some caves in 1980 (Balák et al., 1999). Corrosion of speleothems was observed in some of the caves and was originally ascribed to changes of water chemistry due to the intensively applied fertilizers (Balák et al., 1999). In order to protect the cave environments and its endemic biota, the fertilized lands above some of the caves and their surroundings have been turned into grasslands in several stages between 1985 and 2009 (Balák et. al., 1999). This change was originally performed within the framework of a voluntary agreement between the board responsible for the protection of the area and farmers; later this was expanded with support
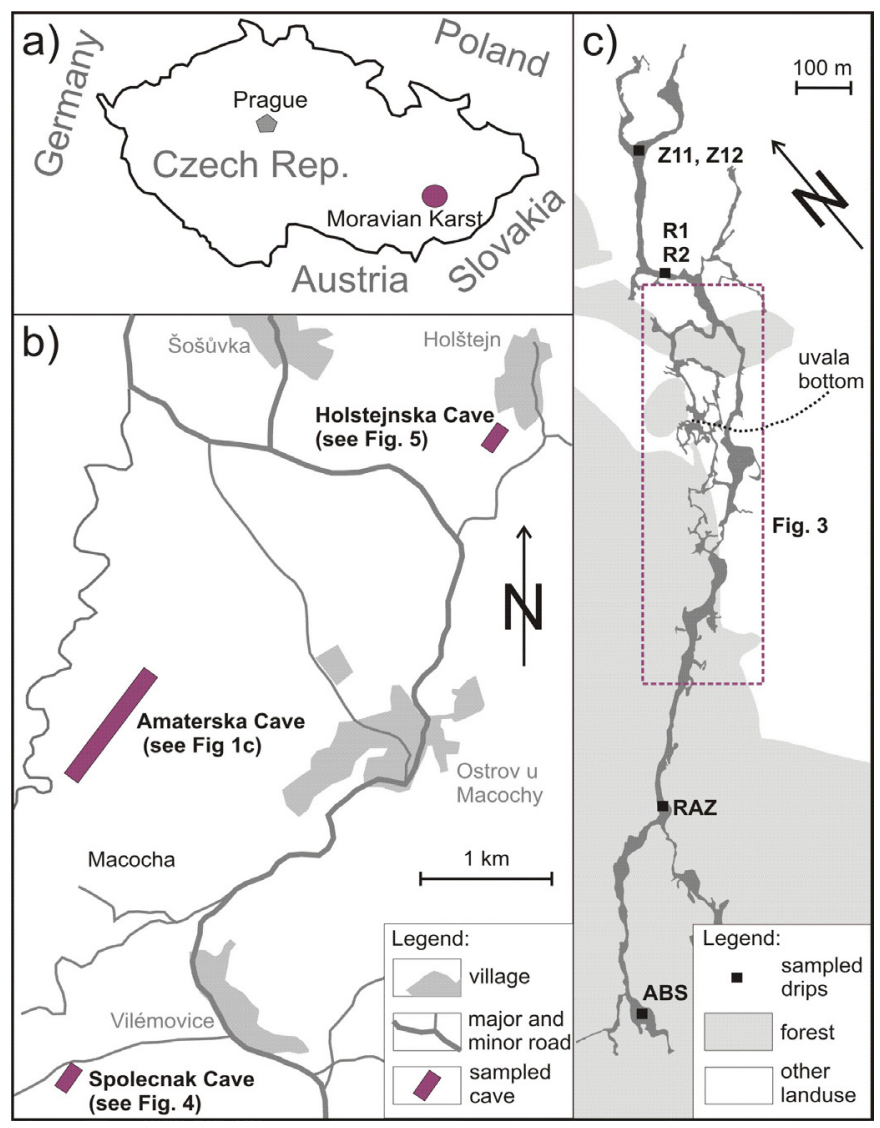

Fig. 1. a) Location of the Moravian Karst within Central Europe; b) Northeastern part of the Moravian Karst with the studied cave systems; c) Amaterska Cave with drips sampled in 1991-1994, and area selected for detailed sampling of drips (rectangular dashedline). Drips in the dashed line rectangle are shown in Fig. 3.

Table 1. Average concentrations of nitrates below areas with different land use in 2007-2010 (mg/l). Samples taken within $18 \mathrm{~m}\left(\mathrm{H}_{\max }\right)$ from $\mathrm{F} / \mathrm{N}$ boundary were not used for calculating the averages.

\begin{tabular}{|c|c|c|}
\hline Cave & Land use & Nitrate \\
\hline \multirow[t]{3}{*}{ Amaterska } & fertilized land & 80 \\
\hline & grassland since 1998 & 78 \\
\hline & forest & 10 \\
\hline \multirow[t]{2}{*}{ Spolecnak } & fertilized land & 104 \\
\hline & grassland since 1850 & 11 \\
\hline \multirow[t]{2}{*}{ Holstejnska } & grassland since 2003 & 37 \\
\hline & forest & 5 \\
\hline
\end{tabular}

of the EU program Sapard. Neither livestock nor the release of animal waste is allowed in grassland areas. The grass is cut and transported out of the grassland areas to decrease the nitrate content in the soil and the karst vadose zone. Based on information from employees of the Moravian Karst protected landscape area (as well as our own observations), the farmers comply with these restrictions. Presently, the planning is towards optimizing the grassland areas above the caves to a smaller extent; still ensuring the protective function, but minimizing the costs paid to farmers for restrictions on their agricultural activities.

The objective of this study is to evaluate: 1) the horizontal component of nitrate transport in the karst vadose zone, which is critical in selecting the correct width of overlap of the grass strips over the cave outlines; 2) the mean residence time of nitrate in the karst vadose zone, which is an important parameter necessary to estimate the time until the nitrate 
concentrations in the drips will reach their presentday background after a change of fertilized land into grassland. The study is focused on the Moravian Karst; however, the results of the horizontal transport component are compared with similar studies from other regions in order to infer those parameters that might control the range of horizontal transport.

\section{STUDY AREA}

The study area is situated in the Moravian Karst, $200 \mathrm{~km}$ SE of Prague (Fig. 1). The Moravian Karst consists of a folded and faulted high-percentage limestone sequence of Devonian age, which is $25 \mathrm{~km}$ long, several $\mathrm{km}$ wide, and $\sim 600 \mathrm{~m}$ thick. Welldeveloped karst phenomena comprise $\sim 1,600$ caves as well as hundreds of dolines and blind valleys (Bruthans $\&$ Zeman, 2003). Caves have been evolving by the activity of sinking alogenic streams. The latest phase of a continuous karstification started in the Pliocene (Kadlec et al., 2001). The Moravian Karst was subjected to periglacial and permafrost conditions during glacial periods; however, was never glaciated itself (Žák et al., 2004). All of the main caves are oriented in the direction of cleavage, faults, and calcite veins (Dvořák \& Melichar, 2002). Most fractures are subvertical, striking between NNW and NNE. The bedding planes are inclined toward the NW-NE-SE, dipping $15-80^{\circ}$. The mean annual air temperature and precipitation totals are $7.2{ }^{\circ} \mathrm{C}$ and $616 \mathrm{~mm}$, respectively. Precipitation is more abundant from May to September (rain, storms), and the snow cover occurs between December and March. Recharge dominates between December and May. The evapotranspiration to precipitation ratio is $~ 82 \%$ at the altitude of the Moravian Karst, based on a water budget study (Taraba, 1976).

Drips were sampled in the Amaterska, Spolecnak, and Holstejnska caves. Each cave is situated below the $\mathrm{F} / \mathrm{N}$ boundary, which always runs between fertilized land and that area where fertilizers have not been applied (forest or grassland; Fig. 2). The F/N boundary produces a sharp change in the nitrate concentrations in both the soil and the vadose zone. The horizontal component of nitrate transport in the vadose zone can be estimated from the width of the transition zone between those regions with low and high nitrate concentrations in their cave drips (Fig. 2). In the case of all the caves, the F/ $\mathrm{N}$ boundary is enclosing an area that for $\geq 160$ years has not been used for agriculture, and where fertilizers have never been applied; with the exception of the tree nurseries, which have been limited in both time and space (Figs. 3, 4, 5).

The Amaterska Cave is a large maze of passages situated 105-120 $\mathrm{m}$ below the surface, which enables sampling in various directions across the F/N boundary (Fig. 3). The SE part of the cave has been overlain by forest for at least 160 years $\left(2^{\text {nd }}\right.$ Military Survey, 1852). Over a small segment of the cave there is a tree nursery in the forest where fertilizers were applied. The central part of this area was fertilized until 1998, when it was converted into grassland. Further north, there are two patches,

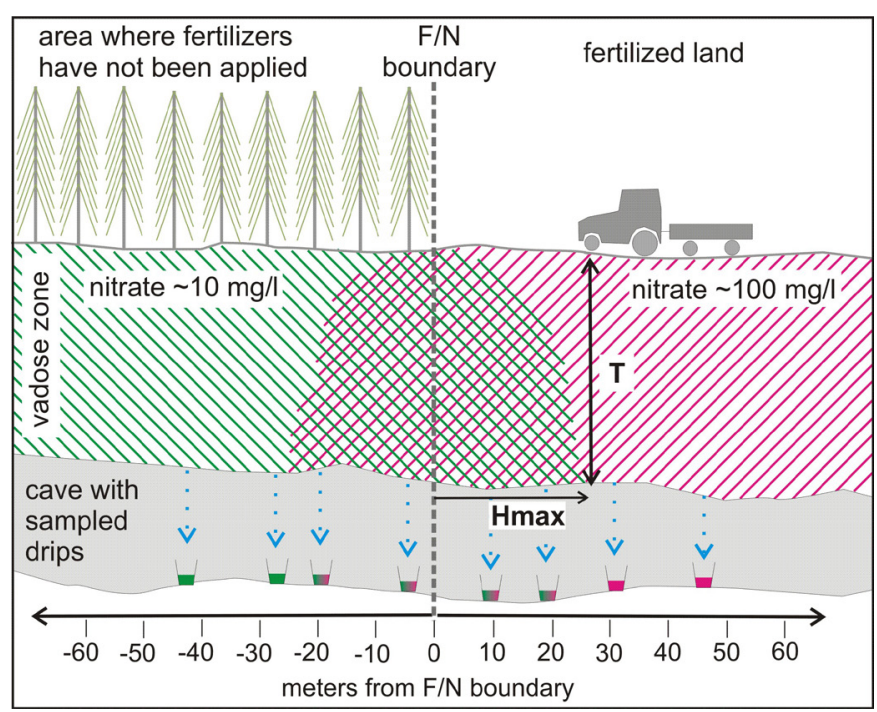

Fig. 2. Conceptual model of horizontal component of mixing on $F / N$ boundary, and definition of the $\mathrm{H}_{\max }$ and $\mathrm{T}$ parameters. The distance from the boundary towards fertilized land (at the present or in the past) is measured in positive numbers, and the distance towards forest (land never fertilized) is in negative numbers.

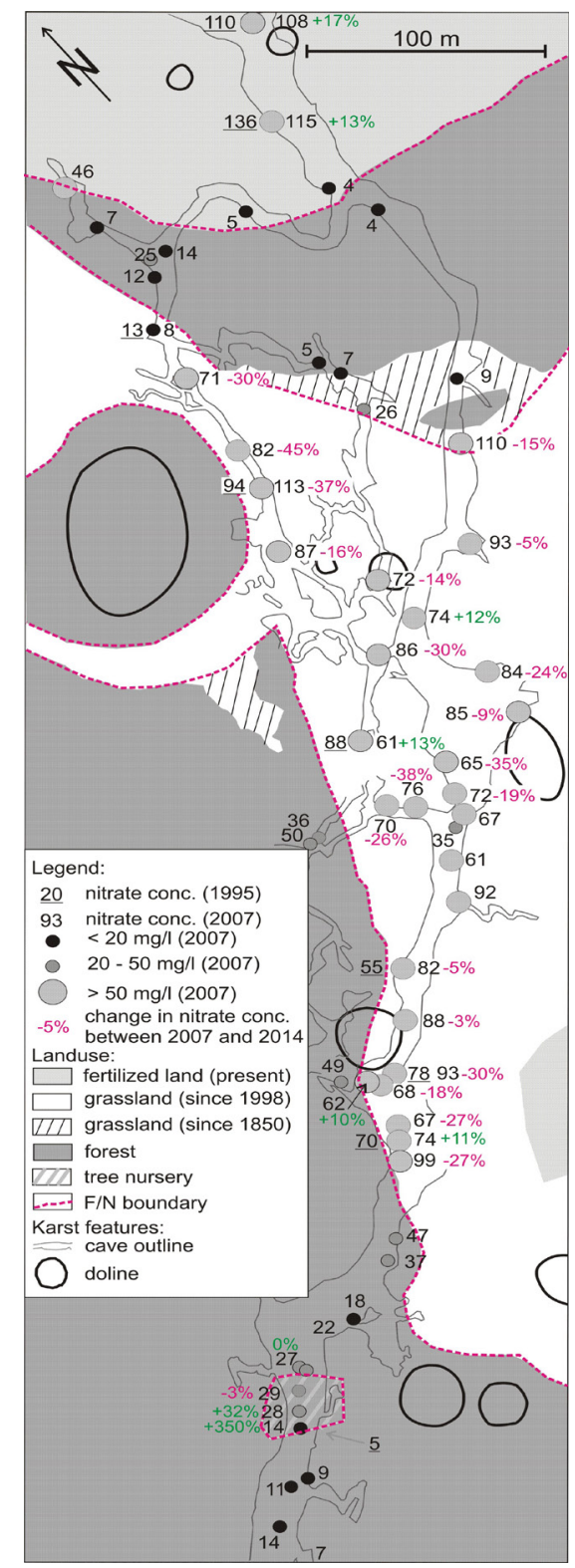

Fig. 3. Land use, cave and doline outlines, plus nitrate concentration in drips in the Amaterska Cave. Cave outline modified from Hromas et al. (2009). Land use is based on the 2nd Military Survey (1852) and current land use maps. 
with trees and shrubs that have not been used for agricultural activities for at least 160 years ( $2^{\text {nd }}$ Military Survey, 1852). Fertilized land covers the northernmost portion of study area (Fig. 3). The surface above the cave is relatively flat (gradient from 0.02-0.09). Higher surface gradients are found on the sides of the uvala depression (up to 0.24), which crosses the central part of cave (Fig. 1). The soil profile is formed by rendzina, with a thickness of 0.5-0.7 $\mathrm{m}$ in the forested area above the cave (Schwarcová et al., 2006). The soil thickness is higher on the fertilized land.

Spolecnak Cave is a large elongated hall situated 60-85 m below the surface (Fig. 4). Grass, shrubs, and trees cover two dolines above the cave. The remaining surface is made up of fertilized land. The $\mathrm{F} / \mathrm{N}$ boundary has not changed for at least 160 years $\left(2^{\text {nd }}\right.$ Military Survey, 1852). The surface above the

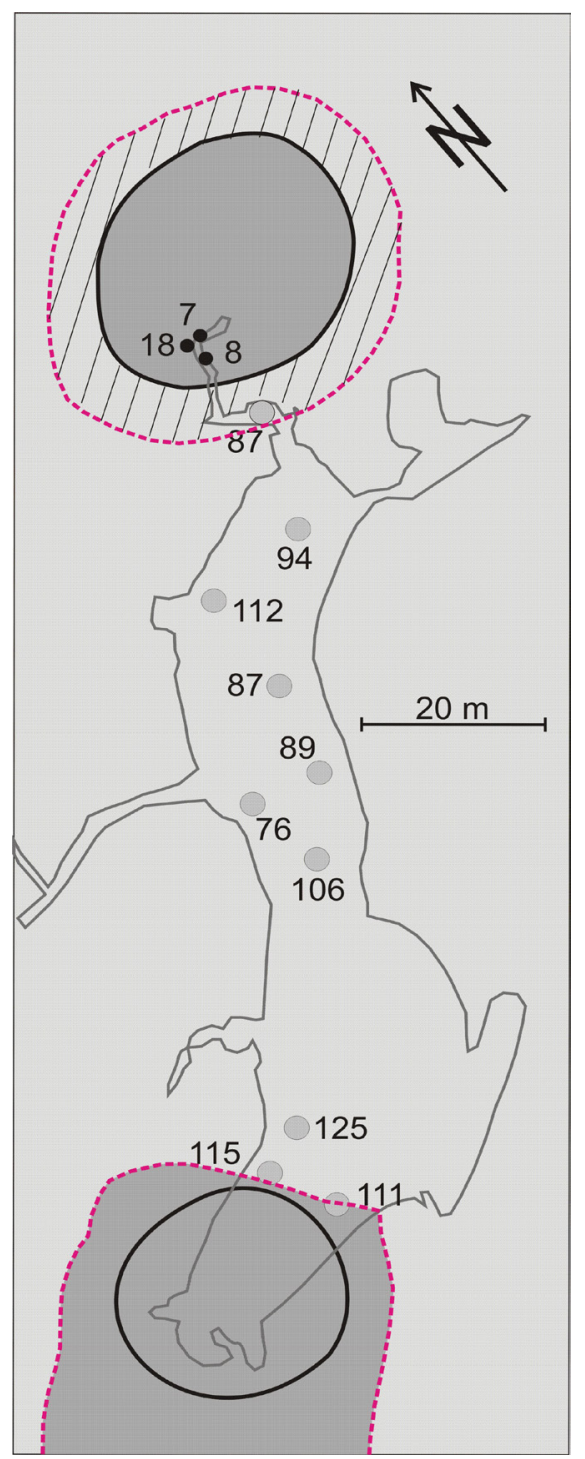

Fig. 4. Land use, cave and doline outlines, and nitrate concentration $(\mathrm{mg} / \mathrm{l})$ in drips in the Spolecnak Cave. Cave outline modified from Hromas et al. (2009). Fertilized land covers the whole area, except the dolines. Drips were sampled in June 2010. See Fig. 3 for legend.

cave is relatively flat (gradient 0.02), except for the sides of the dolines.

Holstejnska Cave is a huge cave passage filled to its ceiling with gravels. It is situated $25-30 \mathrm{~m}$ below the surface (Fig. 5). Cavers dig small galleries crossing the sedimentary fill in various directions. The eastern part of cave has been overlain by forest for at least 160 years. The central and western parts of the cave were once situated below fertilized land, which was converted to grassland in 2003 (Fig. 5). The surface above the cave is flat (gradients 0.05-0.08), except for the entrance portion of the cave, which is below a steep slope.

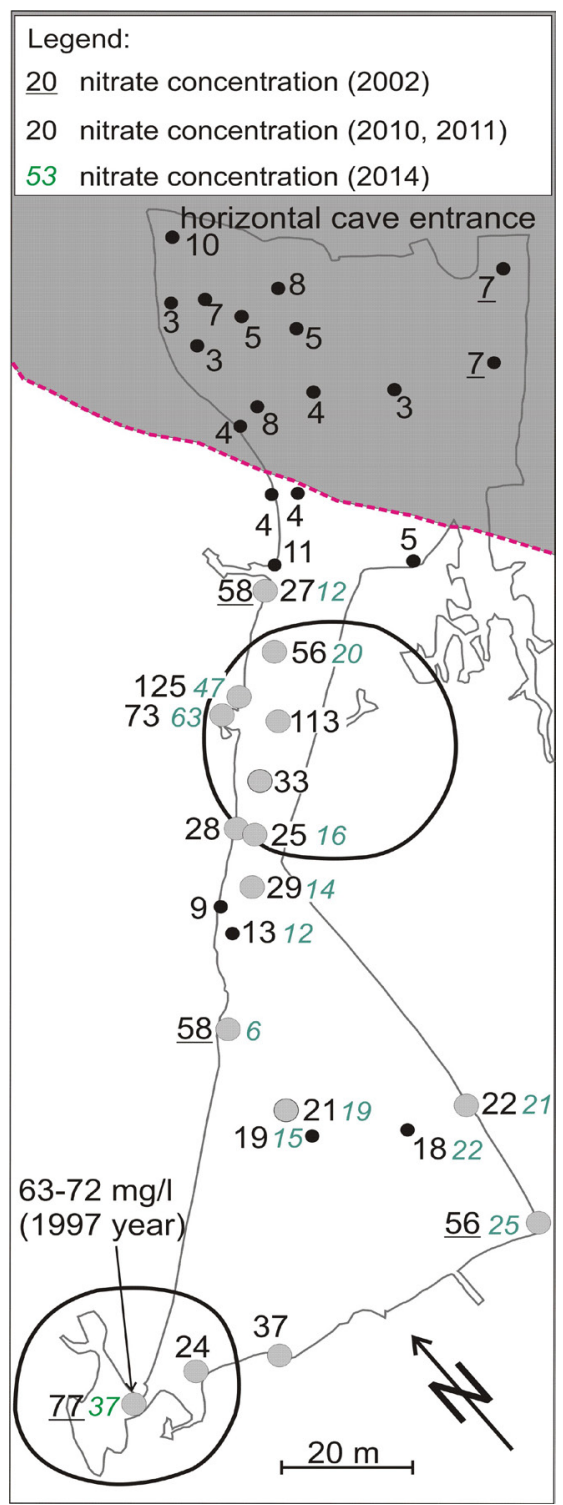

Fig. 5. Land use, cave and doline outlines, and nitrate concentration in drips in the Holstejnska Cave. Cave outline modified from Hromas et al. (2009). Nitrate concentration was monitored in one drip in 1997 (Himmel, 1997) and several drips in 2002 (Jančo, 2002). See Fig. 3 for legend. White area was converted to grassland in 2003.

\section{METHODS}

Using GIS, the caves were projected onto a land use map, and those cave passages within distances up to $160 \mathrm{~m}$ from the $\mathrm{F} / \mathrm{N}$ boundary were selected for the study. The drips were located in the caves, and the direct horizontal distance between the drips and the $\mathrm{F} / \mathrm{N}$ boundary was measured in a GIS. Those distances from the $\mathrm{F} / \mathrm{N}$ boundary to within fertilized lands are marked by positive numbers, and those distances from the $\mathrm{F} / \mathrm{N}$ boundary to within unfertilized lands are marked by negative numbers (Fig. 2).

The sampling and analyses of these drips were done over several periods. In 1991-95 and 2002 the 
drips were sampled to 1 liter PE bottles. Several tens of drips were sampled, some of them on a monthly basis. Drip intensity was measured either by the number of drips per minute or by the volume of water collected per unit time. The nitrate concentration was analyzed by photometry in the laboratory of the Nature Conservation Agency of the Czech Republic.

Drips sampled in 2007 and later were collected in PP buckets rinsed by deionized water placed below the drips for 24 hours. Sampling in the Amaterska Cave was performed in July of 2007 and March of 2014. Sampling in the Spolecnak Cave was performed in June, 2010. As there were no changes in the landuse pattern, sampling was not repeated in this cave. Sampling in the Holstejnska Cave was performed in June of 2010, June of 2011, and March of 2014. All cave drips were sampled within one or two days, in order to suppress possible temporal variations. The sampled water was filtered by Nalgene vacuum filtration system $(0.45 \mu \mathrm{m}$ Millipore filter) and stored in Nalgene HDPE bottles in the cold. The nitrate, chloride, and sulfate concentrations were measured by HPLC Dionex (USA) in the Laboratories of the Geological Institutes of the Charles University in Prague. The analytical error was $1-3 \%$ RSD (depending on the concentration, calculated from 3 replicates). A blank was used during the entire analytical process, with its value subtracted from the measured values.

The nitrate concentrations in each cave were plotted against their distance from the F/N boundary. Envelope curves were constructed, which encompass maximum nitrate concentrations on the forest side of the boundary, and minimum nitrate concentrations at the fertilized side of boundary (Fig. 6a). One outlier is discussed in chapter results and discussion. The maximum range of horizontal transport of nitrate $\left(\mathrm{H}_{\max }\right)$ was defined by the greatest distance between the F/N boundary and envelope curves (Fig. 6). To compare the horizontal transport in the various caves, which differ in the thickness of their vadose zones, the $\mathrm{H}_{\max }$ was divided by the thickness (T) of the vadose zone above each cave (Fig. 2).

The mean residence time of nitrate in the vadose zone was determined from the time lag between the change of fertilized land to grassland, and the time when the nitrate concentration in the drip decreased to $55 \mathrm{mg} / 1$, which is roughly the midpoint between the nitrate concentration in the drips below forest/grassland and fertilized land (Table 1). Such a definition of the mean residence time is the analog of tracer tests, with an instantaneous decrease of constant concentration $\mathrm{C} 1$ at the input point to another constant value $\mathrm{C} 2$ (step-injection; Käss et al., 1998). In such a case, the mean residence time is defined as the time period between the change of concentration at the input point and the time when the concentration at the sampling point reaches the midpoint between the $\mathrm{C} 1$ and $\mathrm{C} 2$ concentrations (Käss et al., 1998). This definition of mean residence time is valid for a conservative tracer in various environments, including the karst vadose zone. Nitrate is commonly considered a conservative tracer in a karst vadose zone (Jeannin et al., 2007).
$\mathrm{C} 1$ is the average concentration in drips below fertilized lands, while $\mathrm{C} 2$ is the average concentration of nitrates in drips below forests. As there are only minor temporal variations of $\mathrm{C} 1$ and $\mathrm{C} 2$ concentrations (Temporal variation of nitrate concentration and nitrate mean residence time in the vadose zone), and the change in landuse was abrupt, this approach should be applicable for selected areas.
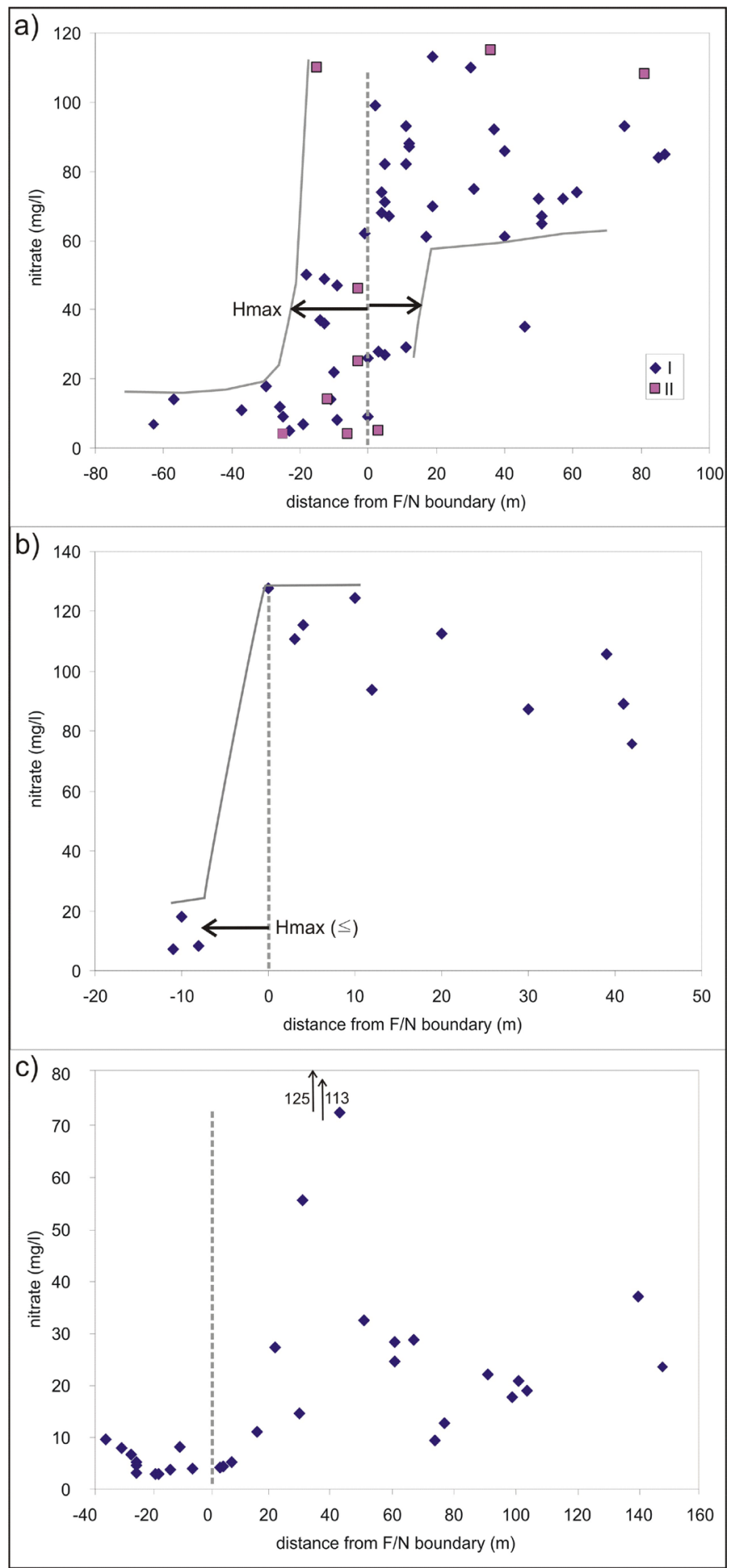

Fig. 6. Nitrate concentration in drips plotted over the distance from the F/N boundary. a) Amaterska Cave; b) Spolecnak Cave; c) Holstejnska Cave; I) Drips sampled on the boundary between fertilized land converted into grassland in 1998 and forest; II) Drips sampled on the boundary between presently fertilized land and forest. The distance from the boundary towards fertilized land (at the present or in the past) is measured in positive numbers, and the distance towards forest (never fertilized land) is in negative numbers. Dashed line shows the position of the F/N boundary. Grey continuous lines show the data envelope. Arrows in diagram c show nitrate concentrations exceeding diagram range. 


\section{RESULTS AND DISCUSSION}

\section{Horizontal component of nitrate transport in the vadose zone}

Nitrate concentrations were analyzed from 60 drips in the Amaterska Cave, sampled in June, 2007. The mean nitrate concentration in the drips in the areas never fertilized was $10 \mathrm{mg} / 1$; in the area originally fertilized but converted to grassland in 1998 it was $78 \mathrm{mg} / 1$; and in presently-fertilized land it was $80 \mathrm{mg} / 1$ (Table 1). The differences in nitrate concentrations between the two latter land-use categories are negligible (Fig. 6a). Therefore, the $\mathrm{F} / \mathrm{N}$ boundary is enclosing the land never fertilized (Fig. 4). A abrupt change in the nitrate concentration exists at the F/N boundary (Fig. 3). Concentrations typical for forest change into concentrations typical for fertilized land within a few tens of meters (Fig. 6a). $\mathrm{H}_{\max }$ is $18 \mathrm{~m}$, and $\mathrm{H}_{\max } / \mathrm{T}$ is $0.15-0.17$ in the $105-120 \mathrm{~m}$ thick vadose zone. One outlier in Fig 6a indicates that either $~ 5 \%$ of the flow has a higher horizontal component or water in the drip has lower residence time so that nitrates were already leached from vadose zone. The spatial distribution of the nitrate concentrations does not suggest that horizontal transport is higher in some directions (Fig. 3). The existence of dolines had no observable effect on the horizontal nitrate transport or on concentration.

The nitrate concentration was analyzed in 13 drips in the Spolecnak Cave, sampled in June of 2010. Abrupt changes in the nitrate concentration exist at the $\mathrm{F} / \mathrm{N}$ boundary (Fig. $6 \mathrm{~b}$ ). Low concentrations below the doline change into concentrations typical for fertilized lands within less than 10 meters (Fig. $6 \mathrm{~b}$ ). $\mathrm{H}_{\max }$ is $<10 \mathrm{~m}$, and $\mathrm{H}_{\max } / \mathrm{T}$ is $<0.17$ in the $60-85 \mathrm{~m}$ thick vadose zone. The mean nitrate concentration in the area never fertilized is $11 \mathrm{mg} / 1$, in the fertilized land used through the present time it is $104 \mathrm{mg} / 1$ (Table 1).

The nitrate concentration was analyzed in 33 drips in the Holstejnska Cave, sampled in June of 2010, 2011, and March of 2014. Changes in the nitrate concentration at the $\mathrm{F} / \mathrm{N}$ boundary is not pronounced. After the conversion of fertilized land to grassland in 2003, the nitrate concentration dropped to values close to those typical for forested areas in some drips prior to 2010. Therefore, the $\mathrm{H}_{\max }$ cannot be determined (Fig. 6c). The mean nitrate concentration in those areas which were never fertilized was $5 \mathrm{mg} / \mathrm{l}$; with the case of fertilized lands converted into grassland it was $37 \mathrm{mg} / 1$ (Table 1).

The nitrate concentrations found in drips below forests mostly fall within the range of presentday background concentrations summarized by Panno et al. (2006). Slightly increased nitrate concentrations were detected in drips below a former tree nursery, due to occasional fertilizing (Fig. 3). The low horizontal component of nitrate transport in the caves indicates that the grass strip above the cave spaces need only overlap the cave by $20 \mathrm{~m}$ on both sides to ensure that the vadose zone in a cave will not be affected by nitrate from the fertilized land adjacent to the grass strip.

\section{Temporal variation of nitrate concentration and nitrate mean residence time in the vadose zone}

Nitrate concentrations were measured on a monthly basis at several drips in the Amaterska Cave below fertilized land, forest, as well as a tree nursery during the hydrologic years 1992-94 (Fig. 7; drip position Fig. 1). The mean concentrations in the drips below fertilized lands were 61-105 mg/1 (drips R1, R2, Z12, and Z13; Fig. 7). Variability of the nitrate concentrations in the drips was low (coefficient of variation, $\mathrm{CV}, 5-9 \%$ ); on the other hand, the variation of the drips' flow rates was considerable (CV 39-94\%). No relationship was observed between the nitrate concentration and drip flow rates. Nitrate concentrations steadily increased in the case of one drip; in the case of three other drips, no trend in nitrate concentration was observable over a three year period. Nitrate concentration below forest was $3 \pm 1 \mathrm{mg} / 1$ (drip RAZ). The mean nitrate concentration below the tree nursery was $13 \mathrm{mg} / 1$ and the $\mathrm{CV}$ was $13 \%$ (drip ABS). Nitrate concentration below the tree nursery was probably elevated, when compared to a grown forest, due to the fertilizers applied.The absence of annual cycling of nitrate concentrations in the case of all drips indicates that the dominant flow component containing nitrate has a residence time of several years (or more). The high variability of drip rates demonstrates the fast propagation of hydraulic responses via the vadose zone. The hydraulic response often propagates much faster than water particles. Situation where the flow rate varies, but the chemical signal is stable is very common (Perrin et al., 2003b).
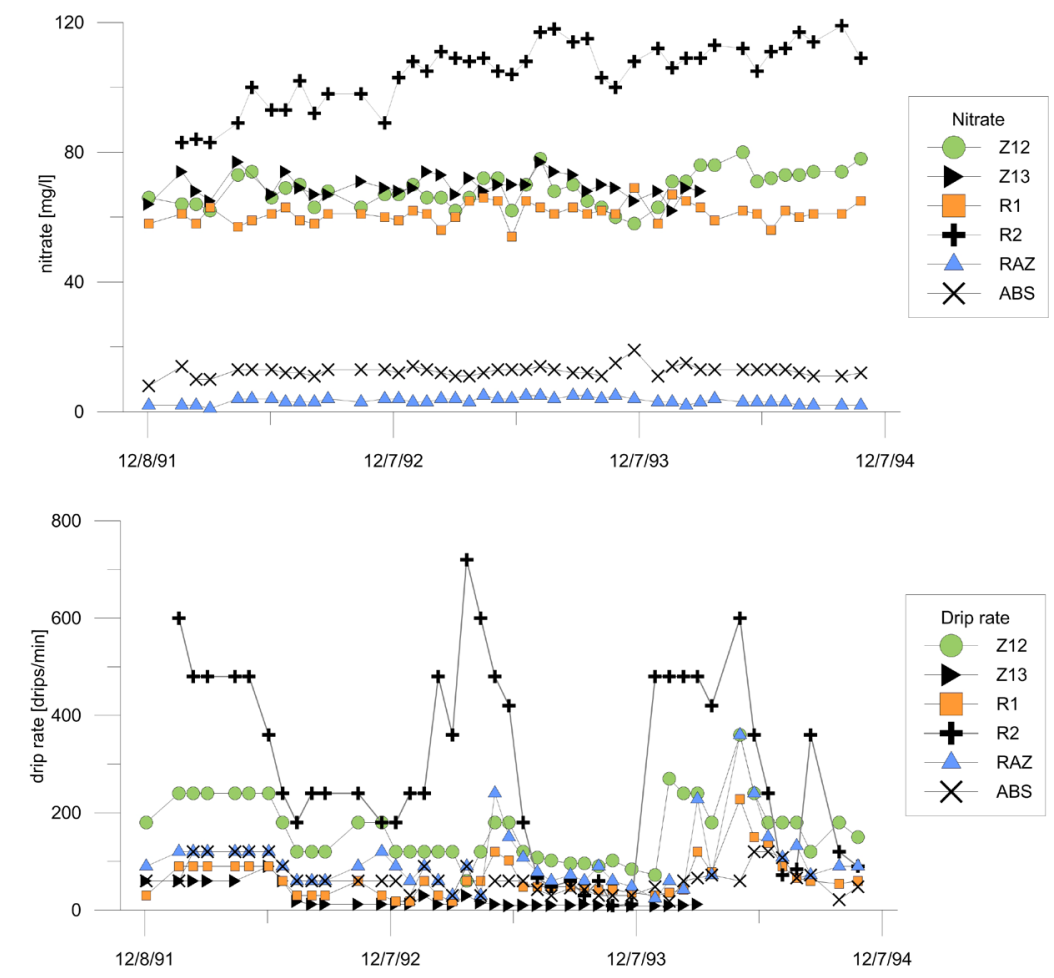

Fig. 7. Nitrate concentration in drips sampled at monthly periods in the Amaterská Cave during hydrologic years 1992-94 (upper panel); Drip flow rate. Drips: Z12, Z13, R1, and R2 - fertilized land, RAZ - forest, ABS - tree nursery (lower panel). 
The nitrate concentrations, occasionally measured in the Amaterska Cave drips in 1995, are shown in Fig. 3. Nitrate concentrations in the drips measured in 1995 and 2007 are similar, even below those areas converted to grassland in 1998. Surprisingly, the nitrate concentration did not significantly decrease within the 9 year period after conversion of the fertilized land to grassland. Twenty three drips sampled in March of 2014 below the area converted to grassland in 1998, showed only a $17 \%$ decrease (on average) in nitrate concentration, compared to 2007 (Fig. 3). The maximum decrease of nitrate concentration was $45 \%$. In $76 \%$ of the drips, the nitrate concentrations were still above $55 \mathrm{mg} / 1$ in 2014. This shows that the mean residence time of nitrate in the 105-120 m thick vadose zone above the Amaterska Cave generally exceeds 16 years.

In case of the Holstejnska Cave, the drips sampled in 2010 below land originally fertilized but converted to grassland in 2003, generally showed nitrate concentrations at only $20-30 \mathrm{mg} / 1$; significantly less than the concentration measured in 2002, prior to the conversion to grassland (Fig. 5). A different situation was found below the doline, in the central part of the cave, where a nitrate concentration up to $125 \mathrm{mg} / 1$ was observed. However, nitrate concentrations measured in March of 2014 were significantly decreased, even below the doline mentioned above. This demonstrates that the mean residence time of nitrate in the vadose zone in most places above the Holstejnska Cave is shorter than 7 years; except in the area below the central doline, where the residence time of the nitrate is closer to 10 years. The difference in the residence times of nitrate between the Amaterska and Holstejnska caves can be explained by the difference in the thicknesses of the vadose zone. The vadose zone in the case of the Amaterska Cave is $\sim 4$ times thicker than in the Holstejnska Cave; and thus theoretically can take four times longer to leach nitrate. For the Amaterska Cave, this means a theoretical nitrate residence time of 28-40 years. In reality, the residence time in the Amaterska Cave's vadose zone will probably be smaller, as larger porosity is to be expected in the epikarst and upper region of the vadose zone, than in the lower portion (Williams, 2008).

\section{Horizontal transport data derived from tracer tests}

To identify those factors potentially affecting the horizontal transport of a dissolved tracer in the karst vadose zone, the data from available artificial tracer tests from the vadose zone of the Moravian Karst, as well as several other areas in temperate climates, were analyzed (Table 2). Before discussing the results of the artificial tracer tests, it is important to mention the most significant differences between the use of environmental and artificial tracers. Nitrate as a typical environmental tracer enters the vadose zone with natural diffuse recharge over the entire area anywhere nitrate is intensively applied (nonpoint source) for a period of many decades. Thus, the nitrate had enough time to arrive at all places where water from fertilized land flows. This is different from artificial tracers, applied to one or a few tens of discrete points (point source), and sampled over a limited time period. An artificial tracer is often injected with an amount of water, which exceeds many times the natural recharge. This excess water may significantly increase the horizontal spread of the tracer. The much smaller concentration contrast in the case of nitrate, compared to an artificial tracer, means that an admixture $<10 \%$ will probably be undetectable in drips in the case of nitrate; while in the case of artificial tracers, much smaller admixtures can be detected (Käss et al., 1998).

Himmel (2009) performed Tracer test A1 in the vadose zone above the Ochoz Cave, which is in southern part of the Moravian Karst (Table 2). KBr was injected into 33 holes situated in a 30 by $30 \mathrm{~m}$ square array. Injection holes were dug below the base of the soil and in the karren field. Only 0.31 of water was used for each injection point, which does not exceed natural recharge. The $\mathrm{H}_{\max } / \mathrm{T}$ was 0.17 in the $60 \mathrm{~m}$ thick vadose zone, with a bedding plane dip of 10-20 (Table 2). Other tracer experiments (A2a and A2b) were performed above the Pekárna Cave $(0.5 \mathrm{~km}$ $\mathrm{SSE}$ of the Ochoz Cave) within a $10 \mathrm{~m}$ thick vadose zone, using $\mathrm{KBr}$ injected at the natural recharge rate (5 1). The $\mathrm{H}_{\max } / \mathrm{T}$ was 0.2 (Himmel, 2009); the previous year the $\mathrm{H}_{\max } / \mathrm{T}$ was 0.4 at the same site, when an excess recharge rate was used (750 1 at a single injection point). In the case of an excess recharge rate, the tracer was probably transported via additional pathways in the vadose zone, which would have stayed dry under a natural recharge rate, and thus displaying a higher $\mathrm{H}_{\max } / \mathrm{T}$.

Tracer test $\mathrm{A} 3$ disclosed a $\mathrm{H}_{\max } / \mathrm{T}$ of $\sim 0.5$ in the $10 \mathrm{~m}$ thick fractured overburden at Sinji Vrh, Slovenia (Veselic \& Čenčur Curk, 2001). The bedding plane's dip was $5-30^{\circ}$. Kogovšek \& Šebela (2004) described two tracer tests in the $100 \mathrm{~m}$ thick vadose zone above the Postojna Cave in Slovenia (tracer test A4). During the first tracing, $5 \mathrm{~m}^{3}$ of water was injected with uranine (excess recharge rate); while in the second case, uranine was transported with rain alone (natural recharge rate). The $\mathrm{H}_{\max } / \mathrm{T}$ was 0.33 for both experiments. In this case, the large amount of water injected artificially did not increase the horizontal spreading of the tracer, but instead increased the tracer concentration (by 10,000 $\times$ ) in one drip.

Tracer test $\mathrm{A} 6$ reached a $\mathrm{H}_{\max } / \mathrm{T} \sim 0.7$ at the Gännsbrunnen test site in the Swiss Jura Mountains (Flyn \& Sinreich, 2010; Sinreich \& Flynn, 2011) in an artificial gallery located $10 \mathrm{~m}$ below the ground surface, with a shallow soil and fissured Jurassic limestone dipping 0-45 ${ }^{\circ}$ (Flynn \& Sinreich, 2010). The injection of tracers (fluorescent dye, $\mathrm{Br}^{-}, \mathrm{I}^{-}$, microorganisms, etc.) was performed on the surface via a sprinkler with short pulse tests, as well as a prolonged injection test (flow rate $55 \mathrm{~mm} /$ hour for up to 6 hours, excess recharge rate).

A different type of flow pattern, with a high $\mathrm{H}_{\max } / \mathrm{T}$, was described by Bottrell \& Atkinson (1992) in the White Scar Cave (Great Britain), as well as by Motyka et al. (2001) in the Zakrzóvek horst (Poland), in horizontally bedded Carboniferous and Jurassic limestones, respectively. In both cases, the tracer 
Table 2. $\mathrm{H}_{\text {max }} / \mathrm{T}$ in studied tracer tests. $\mathrm{E}$ - environmental tracer; A - artificial tracer test.

\begin{tabular}{|l|l|l|l|l|l|l|l|}
\hline No. & \multicolumn{1}{|c|}{ Locality } & \multicolumn{1}{|c|}{ Tracer } & $\begin{array}{l}\text { T (vadose zone } \\
\text { thickness) }\end{array}$ & $\mathrm{H}_{\max }(\mathrm{m})$ & \multicolumn{1}{|c|}{$\mathrm{H}_{\max } / \mathrm{T}$} & $\begin{array}{l}\text { Recharge } \\
\text { rate }\end{array}$ & \multicolumn{1}{|c|}{ Reference } \\
\hline E1 & Amaterska Cave, CR & nitrate & $105-120$ & 18 & 0.17 & natural & this paper \\
\hline E2 & Spolecnak Cave, CR & nitrate & $60-85$ & $<10$ & $<0.17$ & natural & this paper \\
\hline A1 & Ochoz Cave, CR & bromide & 60 & 10 & 0.17 & natural & Himmel (2009) \\
\hline A2a & Pekárna Cave, CR & bromide & 10 & 2 & 0.2 & natural & Himmel (2009) \\
\hline A2b & Pekárna Cave, CR & bromide & 10 & 4 & 0.4 & excess & Himmel (2009) \\
\hline A3 & Sinji Vrh, Slovenia & uranine & 10 & 5 & 0.5 & natural & $\begin{array}{l}\text { Veselic \& Čenčur } \\
\text { Curk (2001) }\end{array}$ \\
\hline A4 & $\begin{array}{l}\text { Postojna Cave, } \\
\text { Slovenia }\end{array}$ & uranine & 100 & 33 & 0.33 & natural & $\begin{array}{l}\text { Kogovšek \& Šebela } \\
\text { (2004) }\end{array}$ \\
\hline A5 & $\begin{array}{l}\text { Pivka Jama, } \\
\text { Slovenia }\end{array}$ & uranine & 40 & 20 & 0.5 & excess & Kogovšek (1997) \\
\hline A6 & $\begin{array}{l}\text { Gännsbbrunnen, } \\
\text { Switzerland }\end{array}$ & bacteriophages & 10 & 7 & 0.7 & excess & $\begin{array}{l}\text { Flynn \& Sinreich } \\
\text { (2010) }\end{array}$ \\
\hline A7 & $\begin{array}{l}\text { White Scar Cave, } \\
\text { Yorkshire, GB }\end{array}$ & $\begin{array}{l}\text { fluorescent } \\
\text { tracers }\end{array}$ & $45-90$ & 140 & $1.6-3.1$ & excess & $\begin{array}{l}\text { Bottrell \& Atkinson } \\
\text { (1992) }\end{array}$ \\
\hline A8 & $\begin{array}{l}\text { Zakrzóvek horst, } \\
\text { Poland }\end{array}$ & $\begin{array}{l}\text { chloride, } \\
\text { uranine }\end{array}$ & $5-15$ & 120 & $8-24$ & natural & Motyka et al. (2001) \\
\hline A9 & $\begin{array}{l}\text { GB Cave, Mendip } \\
\text { Hills, GB }\end{array}$ & $\begin{array}{l}\text { fluorescent } \\
\text { tracers }\end{array}$ & $<10$ & 80 & 8 & excess & $\begin{array}{l}\text { Smart \& Friederich } \\
\text { (1986) }\end{array}$ \\
\hline
\end{tabular}

apparently moved via discrete paths to several distant drips, while it did not arrive at many drips in between. In both cases, the largest $\mathrm{H}_{\max } / \mathrm{T}$ was noted in tracer tests performed after heavy rains, which could supply large amounts of recharge to the epikarst below the thin soil. In the Zakrzóvek horst, the $\mathrm{H}_{\max } / \mathrm{T}$ was between 8-24. $\mathrm{H}_{\max }$ was $120 \mathrm{~m}$ in the $5-15 \mathrm{~m}$ thick cave overburden. $\mathrm{H}_{\max } / \mathrm{T}$ reached 1.6-3.1 in the 45-90 m thick overburden above the White Scar Cave. Only 51 of water was used at the injection point in the tracer tests in Poland. Thus, at least in Poland, the effect of artificial injection clearly did not cause a very high $\mathrm{H}_{\max } / \mathrm{T}$.

A large horizontal spreading of the tracer at shallow depths (less than $10 \mathrm{~m}$ ), in a wide front with a $\mathrm{H}_{\max } / \mathrm{T}$ $>8$, described by Smart \& Friederich (1986) was based on 6 tracer experiments in the Mendip Hills, Great Britain, in an area with disturbed and mined ground (tracer A9). The tracer was injected into dolines. Part of the tracing was artificially supplied by up to $4 \mathrm{~m}^{3}$ of water, but the authors reported a similar horizontal spreading of the tracer under a natural recharge rate from other tracer experiments.

\section{Possible factors affecting horizontal transport}

A low $\mathrm{H}_{\max } / \mathrm{T}$ of between 0.1 and 0.6 was observed in the Czech and Slovenian areas (E1-2, A1-A5; Fig. 8, Table 2), even for injections greatly in excess of the natural recharge rate (tracer tests A2b, A4). In both karst areas, the latest phase of continuous karstification has lasted at least since the Pliocene
(Kadlec et al., 2001; Pruner et al., 2010). Neither area was ever glaciated. A low $\mathrm{H}_{\max } / \mathrm{T}$ might be the result of both long-term epikarst development and an increase of the capacity of vertical drains, resulting in predominantly vertical transport within the vadose zone.

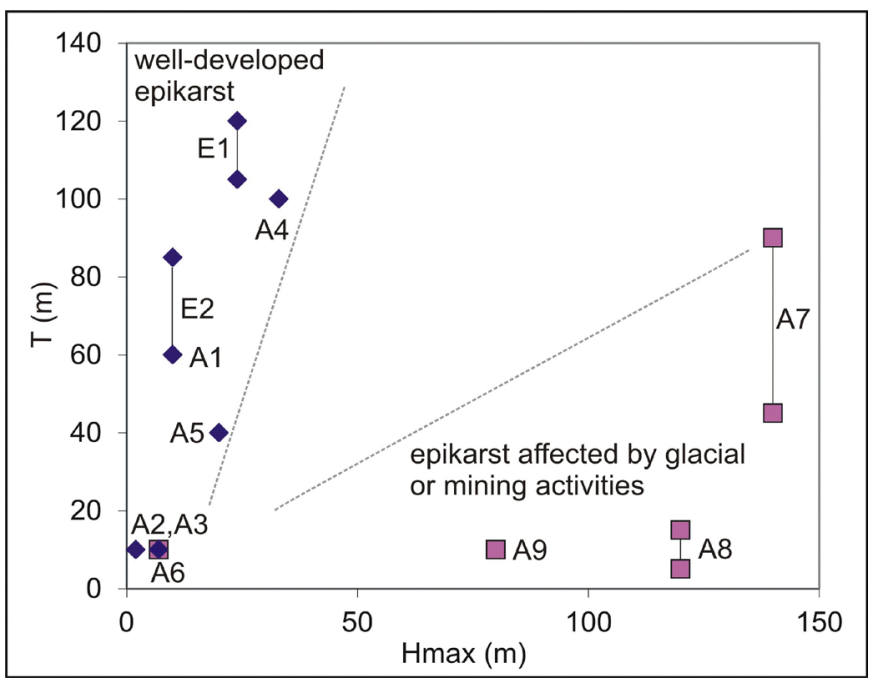

Fig. 8. Comparison of $\mathrm{H}_{\max }$ and $\mathrm{T}$ (maximum) from different areas. Blue diamonds - well-developed epikarst (Moravian and Slovenian karsts); red squares - areas where epikarst was affected by glacial and mining activity.

Tracer tests A7 and A8 were performed in areas that were glaciated in the past (Clark et al., 2003), so that the epikarst zone might have been partly removed or sealed by glacier activity. In both areas, the shallow 
soil does not store much water after heavy rains, and large amounts of water are recharged into the limestone environment, which does not effectively drain downward, and thus the $\mathrm{H}_{\max } / \mathrm{T}$ is high (1.6-24). Tracer test A9 was performed in area affected by mining activities, which might also have negatively affected the epikarst. These observations indicate that the long-term evolution of the epikarst results in a smaller horizontal component of tracer transport in the karst vadose zone as suggested by Williams (2008). The effects of other factors (surface inclination, lithology, fracturing style, dipping of bedding, land-use type, etc.) cannot be assessed due to a dearth of information.

\section{CONCLUSION}

Nitrate concentrations in drips were studied in three caves with a $25-120 \mathrm{~m}$ thick vadose zone in the Moravian Karst, Central Europe during several periods since 1992. Each cave runs below the land-use boundary between fertilized land and forest/grassland, enabling the study of the horizontal component of nitrate transport in the vadose zone. While drips below forested and other never-fertilized land-use categories showed average nitrate concentrations of $5-11 \mathrm{mg} / 1$, those drips below presently-fertilized land showed a mean nitrate concentration of $104 \mathrm{mg} / \mathrm{l}$. Slightly increased nitrate concentrations were detected in drips below a former tree nursery. Portions of the fertilized land were turned into grassland in 1998 and 2003 in order to improve the drip water chemistry. Cave drips were sampled prior to and after the land use change. A considerable residence time of nitrate was observed in the vadose zone. In the case of the 25-30 $\mathrm{m}$ thick vadose zone, the mean residence time of nitrate was between $<7$ and 10 years. In the case of the 105-120 m thick vadose zone, the mean nitrate residence time exceeded 16 years at $76 \%$ of the drips. Temporal variability of the nitrate concentration in the drips was low (coefficient of variation, $\mathrm{CV}=5-9 \%$, while variation of the drip's flow rates was considerable $(\mathrm{CV}=39-94 \%)$. The maximum range of the horizontal component of nitrate transport $\left(\mathrm{H}_{\max }\right)$ reaches $18 \mathrm{~m}$ in the $105-120 \mathrm{~m}$ thick vadose zone. In order to compare the horizontal components of tracer transport in various caves with different thicknesses of their vadose zones, $\mathrm{H}_{\max }$ was normalized by the vadose zone thickness (T). In the Moravian Karst, the $\mathrm{H}_{\max } / \mathrm{T}$ of nitrate does not exceed 0.17.

To identify the possible factors affecting horizontal transport in the karst vadose zone, the data from available artificial tracer tests from the vadose zone of the Moravian Karst and several other areas in temperate climates were analyzed. A low $\mathrm{H}_{\max } / \mathrm{T}$ of between 0.1 and 0.6 is typical for the Czech and Slovenian karst areas, which were unaffected by glaciations, and with an epikarst evolving since at least the Pliocene. On the contrary, a high $\mathrm{H}_{\max } / \mathrm{T}(1.6-24)$ was observed in areas affected by glaciations or mining activities, where the epikarst zone might be partly removed or sealed, and where shallow soils do not store much water after heavy rains. These limited observations indicate that the long-term evolution of epikarst may result in a smaller horizontal component of transport in the karst vadose zone. More data on the horizontal transport of tracers within the vadose zone are needed in order to test this potential relationship. The low horizontal component of nitrate transport in caves indicates that the grass strip above cave spaces in the Moravian Karst only needs to have an overlap of $20 \mathrm{~m}$ to ensure that the vadose zone in the cave will not be affected by nitrate from fertilized land adjacent to the grass strip. After turning the fertilized land into grass strips, it may take up to 20-40 years to decrease the nitrate concentration in the drips to close to presentday background concentrations in the $\sim 100 \mathrm{~m}$ thick vadose zone. As karst settings are highly variable, the low horizontal transport and high residence time of nitrates in the vadose zone should not be applied to other areas until properly tested in the area of interest.

\section{ACKNOWLEDGEMENTS:}

The authors are indebted to I. Balák, L. Štefka, A. Tůma, and K. Šebková from the Nature Conservation Agency for their long-term support of the cave drip research; and to E. W. Peterson and two anonymous reviewers for their valuable comments on the manuscript. The research was supported by Project No. 80509 of the Grant Agency of Charles University, along with research project MSM00216220855, and also by Ceskomoravsky Cement a.s.

\section{REFERENCES:}

Atkinson T.C., Hess J.W. \& Harmon R.S., 1985 - Stable isotope variations in recharge to a karst aquifer, Yorkshire dales, England. Annales de la Société Géologique de Belgique, 108: 225.

Balák I., Jančo J., Štefka L. \& Bosák P., 1999 - Agriculture and nature conservation in the Moravian Karst (Czech Republic). International Journal of Speleology, 28B: 71-88. http:/ / dx.doi.org/10.5038/1827-806X.28.1.5

Bottrel H.A. \& Atkinson T.C., 1992 - Tracer study of flow and storage on the unsaturated zone of a karstic limestone aquifer. In: Hötzl,H., Werner, A.(Eds.) -Proceedings of the 6 th international symposium on water tracing. Balkema. Rotterdam: 207-211.

Boyer D.G. \& Pasquarell G.C., 1995-Nitrate concentrations in karst springs in an extensively grazed area. Water Resources Bulletin, 31: 729-736.

http://dx.doi.org/10.1111/j.1752-1688.1995.tb03397.x

Bruthans J. \& Zeman O., 2003 - Factors controlling exokarst morphology and sediment transport through caves: comparison of carbonate and salt karst. Acta Carsologica, 32: 83-99.

Clark C.D., Evans D.J.A., Khatwa A., Bradwell T., Jordan C.J., Marsh S.H., Mitchell W.A. \& Bateman M.D., 2003 Map and GIS database of glacial landforms and features related to the last British Ice Sheet. Boreas, 33: 359-375. http://dx.doi.org/10.1111/j.1502-3885.2004.tb01246.x

Dvořák V. \& Melichar R., 2002 - The outline of tectonic structure of the northern part of The Moravian Karst. Geological research in Moravia and Silesia in 2001: 51-54 (in Czech).

Einsiedl F., 2005 - Flow system dynamics and water storage of a fissured-porous karst aquifer characterized by artificial and environmental tracers. Journal of Hydrology, 312: 312-321.

http://dx.doi.org/10.1016/j.jhydrol.2005.03.031 
Ford D. \& Williams P., 2007 - Karst hydrogeology and geomorphology. John Wiley \& Sons, Chichester, 562 p. http://dx.doi.org/10.1002/9781118684986

Flynn R.M. \& Sinreich M., 2010 - Characterization of virus transport and attenuation in epikarst using short pulse and prolonged injection multi-tracer testing. Water Research, 44: 1138-1149. http://dx.doi.org/10.1016/j.watres.2009.11.032

Himmel J., 1997 - Contribution for understanding the flux of nitrate in karst catchment. Czech Speleological Society, Speleoforum, 14: 18-20 (in Czech).

Himmel J., 2009 - Research of water movement through vadose zone by tracer tests in the Ochozská and Pekárna caves in the the Moravian Karst. Czech Speleological Society. Speleoforum, 28: 131-135 (in Czech).

Hromas J., 2009 - Jeskyne. Agentura ochrany prirody a krajiny CR and EkoCentrum, Praha, 608 p. (in Czech).

Igbal M.Z. \& Krothe N.C., 1995 - Infiltration mechanism related to agricultural waste transport through the soil mantle to karst aquifer of southern Indiana, USA. Journal of Hydrology, 164: 171-172. http:/ / dx.doi.org/10.1016/0022-1694(94)02573-T

Jančo I., 2002 - Base line monitoring of dissolved solids in drips of Holstejn Cave prior turning the agricultural land to grassland. Cortusa, Blansko: 12 p. (in Czech).

Jeannin P.Y., Groves C. \& Häuselman P., 2007 Speleological investigations. In: Goldscheider N. \& Drew D. (Eds.) - Methods in Karst Hydrogeology. International Contributions to Hydrogeology. Taylor \& Francis, London: 25-44.

Kadlec J., Hercman H., Beneš V., Šroubek P., Diehl J.F. \& Granger D., 2001 - Cenozoic history of the The Moravian Karst (Northern segment): Cave sediments and karst morphology. Acta Musei Moraviae, Scientiae Geologicae, 84: 111-160.

Käss W., Behrens H., Himmelsbach T., Hötzl H., Hunkeler D., Leibundgut C.H., Moser H., Rossi P., Schultz H.D., Stober I. \& Werner A., 1998 - Tracer technique in geohydrology. Balkema, Rotterdam, 581 p.

Kastrinos J.R. \& White W.B., 1986-Seasonal, Hydrogeologic, and Land-Use Controls on Nitrate Contamination of Carbonate Ground Waters. In: Proceedings of the Environmental Problems in Karst Water. National Well Association: 88-114.

Katz B.G., Chelette A.R. \& Pratt T.R., 2004 - Use of chemical and isotopic tracers to assess nitrate contamination and ground-water age, Woodville Karst Plain, USA. Journal of Hydrology, 289: 36-61.

http://dx.doi.org/10.1016/j.jhydrol.2003.11.001

Klimchouk A.B., 2000 - The formation of epikarst and its role in vadose speleogenesis, In: Klimchouk A.B., Ford D.C., Palmer A.N. \& Dreybrodt W. (Eds.), Speleogenesis. Evolution of Karst Aquifers. Huntsville: National Speleological Society: 91-99.

Kluge T., Riechelmann D.F.C., Wieser M., Spötl C., Sültenfuß J., Schröder-Ritzrau A., Niggemann, S. \& Aeschbach-Hertig W., 2010 - Dating cave drip water by tritium. Journal of Hydrology, 394: 396-406.

http://dx.doi.org/10.1016/j.jhydrol.2010.09.015

Kogovšek J., 1997 - Water tracing tests in vadose zone. In: Kranjc A., (Ed.) - Tracer Hydrology. Balkema, Rotterdam: 167-173.

Kogovšek J. \& Šebela S., 2004 - Water tracing through the vadose zone above Postojnska Jama, Slovenia. Environmental Geology, 45: 992-1001. http://dx.doi.org/10.1007/s00254-003-0958-Z

Motyka J., Rózkowski K. \& Górny A., 2001 - Results of tracer experiments in the zone of aeration on limestones of Zakrzówek horst (Cracow, S Poland). In: 7 th conference on Limestone Hydrology and Fissured Media. Besancon: 257-260.
Panno S.V., Kelly W.R., Martinsek A.T. \& Hackley K.C., 2006 - Estimating background and threshold nitrate concentrations using probability graphs. Ground Water, 44: 697-709.

http://dx.doi.org/10.1111/j.1745-6584.2006.00240.x

Perrin J., Jeannin P.Y. \& Zwahlen F., 2003a - Epikarst storage in a karst aquifer: a conceptual model based on isotopic data, Milandre test site, Switzerland. Journal of Hydrology, 279: 106-124.

http://dx.doi.org/10.1016/S0022-1694(03)00171-9

Perrin J., Jeannin P.Y. \& Zwahlen F., 2003b-Implications of the spatial variability of infiltration-water chemistry for the investigation of a karst aquifer: a field study at Milandre test site, Swiss Jura. Hydrogeology Journal, 11: 673-686.

Peterson E.W., Davis R.K., Brahana J.V. \& Orndorff H.A., 2002 - Movement of nitrate through regolith covered karst terrain, northwest Arkansas. Journal of Hydrology, 256: 35-47.

http://dx.doi.org/10.1016/S0022-1694(01)00525-X

Pronk M., Goldscheider N., Zopfi J. \& Zwahlen, F., 2009 Percolation and particle transport in the unsaturated zone of a karst aquifer. Ground Water, 47: 361-369.

http://dx.doi.org/10.1111/j.1745-6584.2008.00509.x

Pruner P., Zupan-Hajna N., Mihevc A., Bosák P., Venhodová D. \& Schnabl P., 2010 - Paleomagnetic and rockmagnetic studies of cave deposits from Račiška pečina and Pečina $v$ Borštu caves (Classical Karst, Slovenia). Studia Geophysica Geodaetica, 54: 28-48. http://dx.doi.org/10.1007/s11200-010-0002-1

Ravbar N. \& Goldscheider N., 2009 - Comparative application of four methods of groundwater vulnerability mapping in a Slovene karst catchment. Hydrogeology Journal, 17: 725-733. http://dx.doi.org/10.1007/s10040-008-0368-0

Sinreich M. \& Flynn R.M., 2011 - Comparative tracing experiments to investigate epikarst structural and compositional heterogeneity. Speleogenesis and evolution of karst aquifers, 10: 60-67.

Swarzova M., Zatloukalova I., Štelcl J. \& Faimon J., 2006 - Sedimentárnè petrografická charakteristika půdnich profilù na vybraných lokalitách Moravského krasu. Geological research in Moravia and Silesia in 2005: 25-28 (in Czech).

Schwartz K., Barth J.A.C., Postigo-Rebollo C. \& Grathwohl P., 2009 - Mixing and transport of water in a karst catchment: a case study from precipitation via seepage to spring. Hydrology and Earth System Sciences, 13: 285-292.

http://dx.doi.org/10.5194/hess-13-285-2009

Smart P.L. \& Friederich H., 1986 - Water movement and storage in the unsaturated zone of a maturely karstified carbonate aquifer, Mendip Hills, England. In: Proceedings of the Environmental Problems in Karst Terrains and their Solutions Conference, Bowling Green, Kentucky: 59-87.

Taraba J., 1976 - Final report on regional hydrogeology study. - Geotest, Brno, 257 p. (in Czech).

Trček B., 2007 - How can the epikarst zone influence the karst aquifer behavior? Environmental Geology, 51: 761-765.

http://dx.doi.org/10.1007/s00254-006-0387-x

USGS, 2002 - The quality of our nation's waters - Nutrients and pesticides. USGS Circular 1225. Washington, D.C.: U.S. Government Printing Office. 
Veselič M. \& Čenčur Curk B., 2001 - Test studies of flow and solute transport in the unsaturated fractured and karstified rock on the experimental field site Sinji Vrh, Slovenia. In: Seiler K.P. \& Wohnlich S. (Eds.), Proceedings of the $31^{\text {st }}$ Congress of International Association of Hydrogeologists, Balkema, Lisse: 211-214.

Williams P.W., 1983 - The role of the subcutaneous zone in karst hydrology. Journal of Hydrology, 61: 45-67. http:/ /dx.doi.org/10.1016/0022-1694(83)90234-2

Williams P. W., 2008 - The role of the epikarst in karst and cave hydrogeology: a review. International Journal of Speleology, 37: 1-10.

http://dx.doi.org/10.5038/1827-806X.37.1.1
Worthington R.H., Ford D.C. \& Beddows P.A., 2000 Porosity and permeability enhancement in Unconfined carbonate aquifers as a result of solution. In: Klimchouk A.B., Ford D.C., Palmer A.N. \& Dreybrodt W. (Eds.) Speleogenesis: Evolution of Karst Aquifers. Huntsville: National Speleological Society: 77-90.

Žák K., Urban J., Cílek V. \& Hercman H., 2004 Cryogenic cave calcite from several Central European caves; age, carbon and oxygen isotopes and a genetic model. Chemical Geology, 206: 119-136. http://dx.doi.org/10.1016/j.chemgeo.2004.01.012 $2^{\text {nd }}$ Military Survey, 1836-1852, Austrian State Archive/ Military Archive, Vienna, Austria. 